\section{Protein-losing enteropathy associated with Henoch-Schönlein purpura}

\author{
Ayako Nakamura, Tatsuo Fuchigami, \\ Yasuji Inamo
}

Department of General Pediatrics, Nihon University Nerima Hikarigaoka Hospital, Nihon University School of Medicine, Tokyo, Japan

\section{Abstract}

The gastrointestinal manifestations of Henoch-Schönlein purpura include abdominal pain, gastrointestinal bleeding, intussusception, and perforation. Protein-losing enteropathy is rarely associated with Henoch-Schönlein purpura. Two pediatric patients with HenochSchönlein purpura who developed protein-losing enteropathy are reported. Tc- $99 \mathrm{~m}$ human serum albumin scintigraphy is useful in the detection of protein-losing enteropathy.

\section{Introduction}

Henoch-Schönlein purpura (HSP), an immune-mediated disorder, preferentially affecting children. It is characterized by petechiae, arthralgia, and gastrointestinal manifestations, including abdominal pain, gastrointestinal bleeding, intussusception, and perforation. ${ }^{1}$ Histological examination reveals systemic necrotizing vasculitis of small vessels. Protein-losing enteropathy (PLE) is a rare complication of HSP, with only six previous pediatric reports. ${ }^{2-7}$

Here, two pediatric HSP patients who developed PLE are reported, along with a literature review.

\section{Case Report}

\section{Case \#1}

A 4-year-old boy was hospitalized with colicky abdominal pain. There was no recent drug exposure or immunization, and his family history was unremarkable.

Four days before admission, he had low grade fever and vomiting, and was treated by a family physician. Because of continuing abdominal pain, he was admitted to our hospital with suspected acute gastroenteritis. On admission, he had vomiting and abdominal pain. He was $113 \mathrm{~cm}$ tall $( \pm 1.63 \mathrm{SD})$ and weighed $18.4 \mathrm{~kg}( \pm 0.3 \mathrm{SD})$. His temperature was $37.4^{\circ} \mathrm{C}$, his pulse was $98 / \mathrm{min}$, and his general condition was poor, with abdominal tenderness but no guarding, and no purpura.

Admission laboratory tests showed leukocytosis $\left(19 \times 10^{9} / \mathrm{L}, 76.6 \%\right.$ neutrophils $)$, decreased serum total protein $(3.0 \mathrm{~g} / \mathrm{dL})$, albumin $(1.8$ $\mathrm{g} / \mathrm{dL}$,$) and plasma factor XIII activity (17\%),$ and increased fibrinogen (204 mg/dL), thrombin-antithrombin III complex (TAT) (10.1 $\mathrm{ng} / \mathrm{mL}$ ), fibrin/fibrinogen degradation products (FDP) (22.4 ng/mL), and D-dimer (24.1 $\mu \mathrm{g} / \mathrm{mL})$. The immunologic profile was normal except for low IgG $(386 \mathrm{mg} / \mathrm{dL})$. The Guaiac test for fecal occult blood was positive.

On the day after admission, he developed bloody stool and purpura on the lower extremities and scrotum. With a diagnosis of HSP with gastrointestinal involvement, prednisolone (1.5 mg/kg/day), dalteparin (75 $\mathrm{U} / \mathrm{kg} /$ day $)$, and urinastatin $(2,500 \mathrm{U} / \mathrm{kg} / \mathrm{dose})$ were started. There was marked edema of eyelids and upper and lower extremities. The patient's serum albumin decreased to $1.8 \mathrm{~g} / \mathrm{dL}$, necessitating albumin infusion. His plasma factor XIII activity also decreased to $17 \%$, necessitating human antihemophilic factor XIII fraction. Plasma factor XIII and serum albumin levels normalized by the 10th day. He was discharged on the 35 th day.

On plain abdominal CT (Figure 1), diffuse wall thickening in the small bowel and colon and a small amount of ascites were noted.

Tc 99m-human serum albumin (HSA) scintigraphy showed activity in the stomach and duodenum 60 min after injection, suggesting PLE. During the course, no urine abnormalities were detected. His transient hypoproteinemia was likely due to PLE, because it normalized as his abdominal symptoms improved.

\section{Case \#2}

A 5-year-old boy was admitted with abdominal pain, vomiting, bloody stool, and a rash on his legs. He had no recent drug exposure or immunization, and his family history was unremarkable. Seven days before admission, purpura developed on his nose and around his mouth, followed by abdominal pain and purpura on the upper and lower extremities, involving his buttocks one day later. HSP was diagnosed.

Because of continuing abdominal pain, he was admitted to our hospital. On admission, he had vomiting, abdominal pain, and bloody stool. He was $121.8 \mathrm{~cm}$ tall $( \pm 1.9 \mathrm{SD})$ and weighed $22.8 \mathrm{~kg}( \pm 0.8 \mathrm{SD})$. His temperature was $36.9^{\circ} \mathrm{C}$, pulse was $90 / \mathrm{min}$, and blood pressure was $90 / 58 \mathrm{mmHg}$. His general condition was poor, with abdominal tenderness but no guarding, and purpura on the earlobes, lower extremities, and scrotum.

Admission laboratory tests showed leukocytosis $\left(19.3 \times 10^{9} / \mathrm{L}, 88.0 \%\right.$ neutrophils), elevated C-reactive protein $(7.06 \mathrm{mg} / \mathrm{dL})$, decreased serum total protein $(6.1 \mathrm{~g} / \mathrm{dL})$, albumin $(3.1$
Correspondence: Tatsuo Fuchigami,

Department of General Pediatrics, Nihon University Nerima Hikarigaoka Hospital, Nihon University School of Medicine, 2-11-1 Hikarigaoka, Nerima-ku, Tokyo 179-0072, Japan.

E-mail: tfuchi@med.nihon-u.ac.jp

Key words: Henoch-Schönlein purpura, proteinlosing enteropathy, Tc-99m human serum albumin scintigraphy

Contributions: AN wrote the main body of the article under the supervision of TF and YI.

Conflict of interest: the authors report no conflicts of interest.

Received for publication: 21 October 2010.

Revision received: 7 December 2010.

Accepted for publication: 7 December 2010.

This work is licensed under a Creative Commons Attribution 3.0 License (by-nc 3.0).

(C) Copyright A. Nakamura et al., 2010

Licensee PAGEPress, Italy

Pediatric Reports 2010; 2:e20

doi:10.4081/pr.2010.e20

$\mathrm{g} / \mathrm{dL}$ ), and plasma factor XIII activity (46\%), and increased TAT $(20.8 \mathrm{ng} / \mathrm{mL})$, FDP (18.2 $\mathrm{ng} / \mathrm{mL})$, and D-dimer $(18.4 \mu \mathrm{g} / \mathrm{mL})$. The Guaiac test for fecal occult blood was positive. The anti-streptolysin-0 (ASO) titer was 900 IU/mL, and the anti-streptokinase (ASK) titer was 1,280 dil. A throat culture was positive for $\alpha$-hemolytic Streptococcus. Streptococcal infection was diagnosed, and ABPC (100 $\mathrm{mg} / \mathrm{kg} /$ day) was given. With a diagnosis of HSP with gastrointestinal involvement, prednisolone (1.5 mg/kg/day), dalteparin (75 $\mathrm{U} / \mathrm{kg} / \mathrm{day}$ ), and urinastatin (2500 U/kg/dose) were started. Plasma factor XIII and serum albumin levels normalized by the $10^{\text {th }}$ day as his abdominal symptoms improved.

On abdominal CT, diffuse wall thickening was noted in the stomach. Tc-99m-HSA

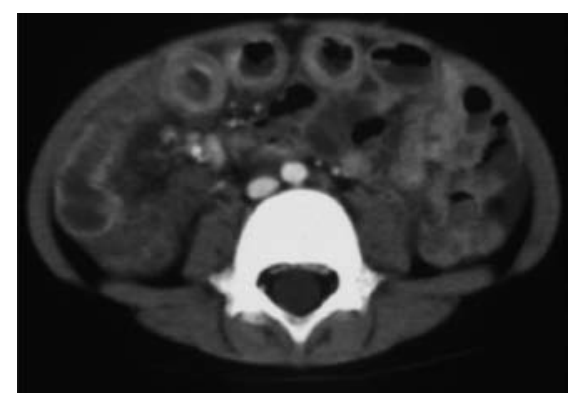

Figure 1. On abdominal computerized tomography, diffuse wall thickening is noted in the small bowel and colon. A small amount of ascites is seen. 
Table 1. Pediatric Henoch-Schönlein purpura patients with protein-losing enteropathy.

\begin{tabular}{|c|c|c|c|c|c|}
\hline Case & Age (years)/sex & Intestinal bleeding & Treatment & Other symptoms & References \\
\hline 1 & $14 / \mathrm{M}$ & $(+)$ & Abdo & ominal pain joint pain, peripheral pitting edema & Reif et al., $1991^{2}$ \\
\hline 2 & $6 / \mathrm{M}$ & $(+)$ & $\begin{array}{r}\text { Abdom } \\
\mathrm{p}\end{array}$ & $\begin{array}{l}\text { ninal pain, urolithiasis, hydrops of the gallbladder, } \\
\text { pancreatic involvement, scrotal hemorrhage, } \\
\text { testicular swelling, pyeloureteritis }\end{array}$ & Bosio et al., $1993^{3}$ \\
\hline 3 & $10 / \mathrm{M}$ & $(+)$ & $\begin{array}{l}\text { PSL, } \\
\text { mPSL pulse }\end{array}$ & $\begin{array}{l}\text { Abdominal pain, hydronephrosis, } \\
\text { gallbladder abnormalities, purpura nephritis }\end{array}$ & Kano et al., $1998^{4}$ \\
\hline 4 & $12 / \mathrm{M}$ & $(-)$ & abdom & minal pain, cerebral vasculitis, testicular swelling & Bakkalo lu et al., $2000^{5}$ \\
\hline 5 & $8 / \mathrm{F}$ & (?) & PSL, F XIII & Abdominal pain & Kaneko et al., 20046 \\
\hline 6 & $4 / \mathrm{M}$ & $(+)$ & PSL & Abdominal pain & Dalgiç et al., $2005^{7}$ \\
\hline 7 & 4/M & $(+)$ & , dalteparin, urinastatin & Abdominal pain & Present report \\
\hline 8 & $5 / \mathrm{M}$ & $(+)$ & dalteparin, urinastatin & Abdominal pain & Present report \\
\hline
\end{tabular}

PSL, prednisolone; mPSL pulse, pulse of methylprednisolone; F XIII, human antihemophilic factor XIII fraction.

scintigraphy showed activity in the stomach 60 min after injection, suggesting PLE. During the course, no urine abnormalities were detected.

\section{Discussion}

Gastrointestinal manifestations of PLE rarely occur with HSP. PLE is a rare condition characterized by gastrointestinal loss of serum protein resulting in hypoproteinemia, which can cause edema, ascites, pleural and pericardial effusions, and malnutrition. Increased capillary permeability or submucosal hemorrhage and ulceration by vasculitis might cause the protein loss. ${ }^{2}$ PLE is rare in HSP, with only eight reported pediatric cases, including our two cases $^{2-7}$ (Table 1). These patients ( 7 boys, 1 girl; age range, 4 to 14 years) all had abdominal pain; four had several unusual complications (case \#\# 2, 3, 4, 6). Case \# $4^{5}$ had abdominal pain, but the stool was Guaiac-negative. Moderate hypoproteinemia (4.9 g/dL) and hypoalbuminemia $(2.5 \mathrm{~g} / \mathrm{dL})$ without proteinuria were detected during the acute phase; the serum protein levels increased gradually on steroid therapy, but severe neurological involvement resulted from cerebral vasculitis. Case \#6, ${ }^{7}$ a 4 -year-old boy, had severe esophagitis and multiple ulcers in the descending duodenum presenting as PLE. However, our cases had PLE without other complications.
Previously, the detection and quantification of gastrointestinal protein loss primarily involved measurement of fecal excretion of albumin labeled with I-125 or Cr-51 after intravenous tracer injection. However, stool collection is difficult, with false-positive results if the stool specimen is contaminated with urine. Subsequently, measurement of fecal excretion of $\alpha 1$-antitrypsin was used to detect PLE. ${ }^{8}$ This serum enzyme, with the same molecular weight as albumin, resists proteolysis and is not degraded when it leaks into the intestinal lumen. However, this is difficult because stool must be collected. Recently, Tc-99m HAS scintigraphy has been used to diagnose PLE by documenting protein loss in the gut, which is also useful for monitoring response to treatment. ${ }^{9-10}$ Our two patients were diagnosed as having PLE because of hypoalbuminemia without nephrosis or liver dysfunction, as well as abnormal leakage of the radiotracer into the gut on Tc-99m HSA scintigraphy. Tc-99m HAS scintigraphy offers a rapid, safe, and convenient way to screen and localize PLE. In HSP patients, Tc-99m HSA scintigraphy is useful for detecting PLE.

\section{References}

1 . Silber DL. Henoch-Schönlein syndrome. Pediatr Clin North Am 1972;19:1061-70.

2. Reif S, Jain A, Santiago J, Rossi T. Protein losing enteropathy as a manifestation of
Henoch-Schönlein purpura. Acta Paediatr Scand 1991;80:482-5.

3. Bosio M, Ravelli A, Ruperto N, et al. The Schönlein-Henoch syndrome with severe multisystem involvement. Minerva Pediatr 1993;45:197-201.

4. Kano K, Ozawa T, Kuwashima S, Ito S. Uncommon multisystemic involvement in a case of Henoch-Schönlein purpura. Acta Paediatr Japonica 1998;40:159-61.

5. Bakkaloğlu SA, Ekim M, Tümer N, et al. Cerebral vasculitis in Henoch-Schönlein Purpura. Nephrol Dial Tansplant 2000;15: 246-8.

6. Kaneko K, Fujii S, Shono T, et al. Diagnostic value of plasma factor XIII in Henoch-Schönlein purpura. Pediatr Nephrol 2004;19:702-3.

7. Dalgiç B, Aktas A, Poyzaz A, Dursun A. Severe esophagitis in a child with HenochSchönlein purpura presenting as proteinlosing enteropathy. Indian J Gastroenterology 2005;24:80-1.

8. Takeda H, Nishise S, Furukawa M, et al. Fecal clearance of alphal-antitrypsin with lansoprazole can detect protein-losing gastropathy. Dig Dis Sci 1999;44:2313-8.

9. Wang SJ, Tsai SC, Lan JL. Tc-99m albumin scintigraphy to monitor the effect of treatment in protein-losing gastroenteropathy. Clin Nucl Med 2000;25:197-9.

10. Seok JW, Kim SJ, Lee SH, et al. Protein-losing enteropathy detected on Tc-99m HAS and Tc-99m MDP scintigraphy. Clin Nucl Med 2002;27:431-3. 